2016

\title{
Ceramic Beads from the Cloud Hammond Site (41SM244), Smith County, Texas
}

Mark Walters

Heritage Research Center, Stephen F. Austin State University

Timothy K. Perttula

Heritage Research Center, Stephen F. Austin State University

Follow this and additional works at: https://scholarworks.sfasu.edu/ita

Part of the American Material Culture Commons, Archaeological Anthropology Commons, Environmental Studies Commons, Other American Studies Commons, Other Arts and Humanities Commons, Other History of Art, Architecture, and Archaeology Commons, and the United States History Commons

Tell us how this article helped you.

This Article is brought to you for free and open access by the Center for Regional Heritage Research at SFA ScholarWorks. It has been accepted for inclusion in Index of Texas Archaeology: Open Access Gray Literature from the Lone Star State by an authorized editor of SFA ScholarWorks. For more information, please contact cdsscholarworks@sfasu.edu. 
Ceramic Beads from the Cloud Hammond Site (41SM244), Smith County, Texas

Creative Commons License

(c) $(1)(9)$

This work is licensed under a Creative Commons Attribution-NonCommercial 4.0 International License 


\title{
Ceramic Beads from the Cloud Hammond Site (41SM244), Smith County, Texas
}

\author{
Mark Walters and Timothy K. Perttula
}

In Volume 85/2014 of the Bulletin of the Texas Archeological Society Jeffery S. Girard, in a very interesting and informative article, "The James Pace Site (16DS268) and Early Caddo Developments Along the Upper Sabine River," describes a barrel-shaped ceramic bead from test units east of Mound A (Girard 2014:73 and Figure 9j). Three other ceramic beads were reported from the same site from 1967 excavations (Jensen 1968:34 and Figure 8m). Girard (2014:73) reported that other examples of ceramic beads, to his knowledge, were unknown in the Caddo area.

During investigations at the Cloud Hammond site (41SM244) during the 1960s, J. A. Walters recovered Caddo ceramics, two clay beads, Perdiz arrow points, and two Gary dart points. The site is located in northern Smith County, Texas, about $400 \mathrm{~m}$ east of the Middle Caddo period Jamestown Mound site (41SM54) (Perttula 2007).

Of the artifacts reported to have been recovered from the site, only one clay bead (Figure 1) was available for study. No record survives of the extent of investigations at the Cloud Hammond site or if any cultural features such as burials were found during the 1960s work.

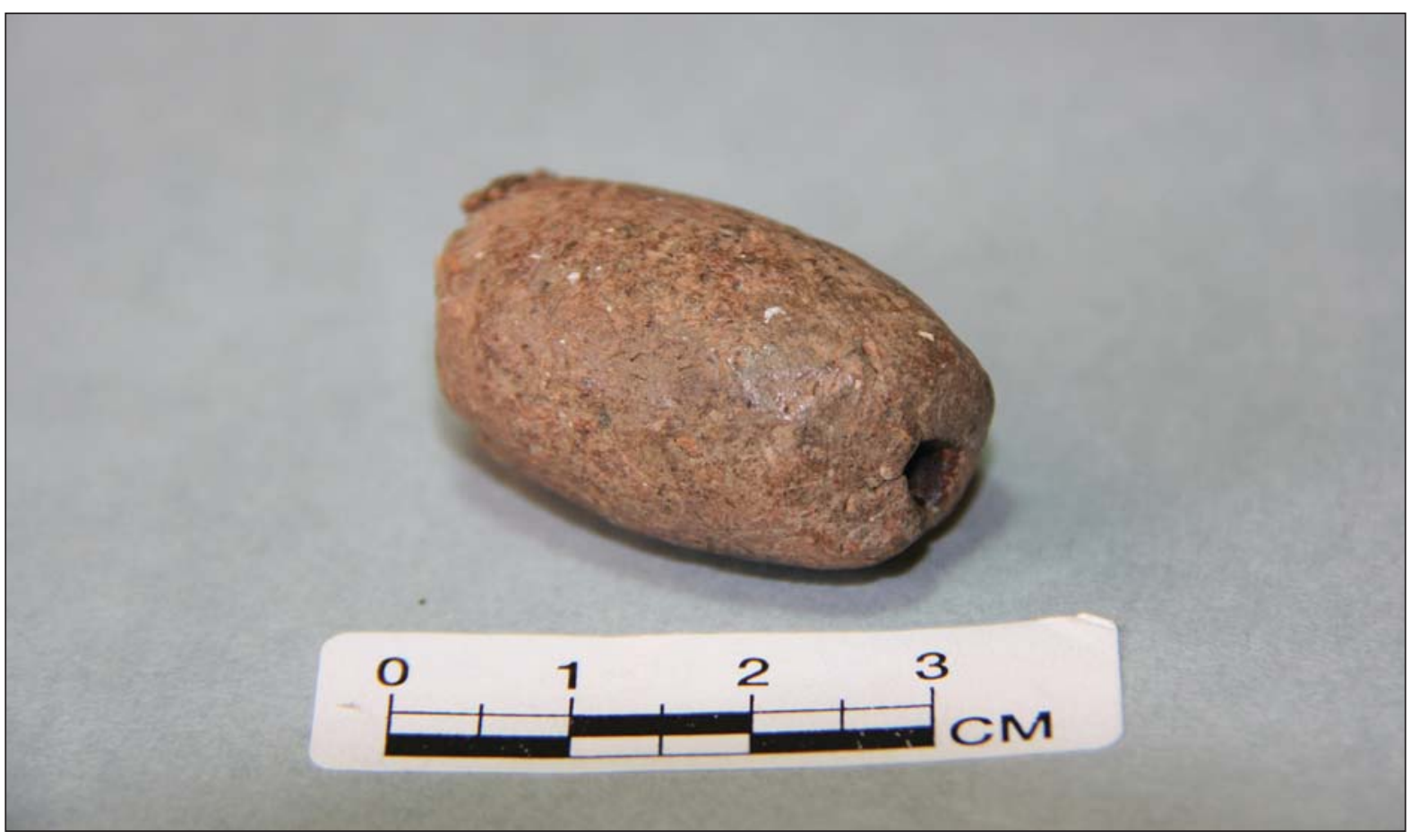

Figure 1. Clay bead from the Cloud Hammond site (41SM244).

The beads were barrel-shaped, flattened on both ends. The dimensions for the one available bead are: length is $3.0 \mathrm{~cm}$ and maximum width is $1.25 \mathrm{~cm}$. The bead has a $2.0 \mathrm{~mm}$ diameter hole. The surviving bead has grog/bone temper, a smooth exterior (that could have been burnished at one time as evidenced by 
patches of luster) and is light grayish-brown in color. There is no evidence of a red slip; the ceramic bead from the James Pace site may have had a red slip (Girard 2014:73).

\section{SUMMARY}

Two ceramic beads were recovered from the Cloud Hammond site (41SM244) in northern Smith County, Texas, during 1960s work by J. A. Walters. These beads are very similar to the beads reported from the James Pace site (16DS268). The James Pace site is an Early Caddo site that was occupied from ca. A.D. 800-1050 (Girard 2014). The Cloud Hammond site has not been radiocarbon-dated but the presence of Perdiz arrow points suggests it may have been occupied during the Middle Caddo period (ca. A.D. 1200-1400). Thus, ceramic beads cannot be considered diagnostic of the Formative or Early Caddo periods.

In fact, delving further into the East Texas archaeological literature indicates that ceramic beads have been found at two Late Caddo period Titus phase sites dating after ca. A.D. 1550 in the upper Sulphur River basin: two beads (15.5-16.5 mm in diameter) at the Tuinier Farm (41HP237) site and three ceramic beads (14-19 mm in length and 10-14 mm in width) at the Anglin (41HP240) sites in the upper Sulphur River basin (Perttula 2009:Figures 41b, 42a-b, and 43b). Furthermore, three other ceramic bead fragments (estimated at 16-20 $\mathrm{mm}$ in length and $12.5-18 \mathrm{~mm}$ in diameter) have been reported from ca. A.D. 1430 1550 Titus phase contexts at the Rookery Ridge site (41UR133) in the Little Cypress Creek basin (Parsons 2015:Figure 9.52e).

It may be culturally significant that these Caddo sites are in the upper parts of the Sabine River, Sulphur River, and Big Cypress Creek basins, and to date, none have been reported elsewhere in the Caddo area. Although beads of marine shell and copper have been found as burial goods on Caddo sites, ceramic beads have not.

\section{ACKNOWLEDGMENTS}

Thanks to Jeff Girard for reviewing a draft of this article and providing comments on it.

\section{REFERENCES CITED}

Girard, J. S.

2014 The James Pace Site (16DS268) and Early Caddo Developments Along the Upper Sabine River. Bulletin of the Texas Archeological Society 85:61-81.

Jensen, H. P., Jr.

1968 Archeological Investigations in the Toledo Bend Reservoir 1966-1967. Archeological Salvage Program, Southern Methodist University, Dallas.

Parsons, M.

2015 Archeological Investigations at Lake Gilmer, Upshur County, Texas Mitigation Phase. Archeology Reports Series, No. 6. Texas Historical Commission, Austin.

Perttula, T. K.

2007 The History of Archaeological Investigations at the Jamestown Mound Site (41SM54), An Archaeological Conservancy Preserve in Smith County, Texas. Caddo Archeology Journal 16:45-56.

2009 The Archaeology of the 16th and 17th Century Caddo in the Post Oak Savannah of Northeast Texas: The Tuinier Farm (41HP237), R. A. Watkins (41HP238), and Anglin (41HP240) Sites in the Stouts Creek Basin, Hopkins County, Texas. Journal of Northeast Texas Archaeology 30:1-132. 


\title{
Bison Remains and Tools on East Texas and Northwest Louisiana Caddo Sites
}

\author{
Timothy K. Perttula
}

\section{INTRODUCTION}

The occurrence of bison bone remains on East Texas and Northwest Louisiana Caddo sites is relatively rare in archaeological contexts, either as food refuse, tools, or ornaments. This article discusses the bison remains found on 26 ancestral Caddo sites in this region. The distribution of bison remains both temporally and spatially across the region provides evidence that bison herds were episodically present in grassland habitats that could be reached by pre-horse Caddo peoples. They also provide direct evidence that certain Caddo communities procured bison at different specific times, most notably after ca. A.D. 1430/1450. Also important is the paleoenvironmental conditions in the archaeological data that may be indicated by the presence of bison hunted by Caddo peoples, particularly those periods amendable to bison, who favored grassland forage. Isotope-based (Carbon and Nitrogen) reconstructions by Lohse et al. (2014b:21-23) suggest bison herds in Central Texas were present during colder periods, periods of rapid climate change, with variations in effective moisture.

In the time period covered by the ancestral Caddo sites discussed below-ca. A.D. 600 to A.D. 1775Lohse et al. (2014a, 2014b) have identified through the direct dating of bison remains two periods where bison were present in the nearby Central Texas region: A.D. 1300-1420 and A.D. 1565-1750 (Central Texas is likely where Caddo hunters would have been able to find bison at certain times, or at least would have been able to obtain bison products of native Central Texans; see Creel [1991].). Archaeological evidence from Caddo sites indicate that they were obtaining bison products during both periods, as well as during pre-A.D. 1200 times, perhaps through trade networks that extended to the north among Caddo peoples living in eastern Oklahoma, where these peoples had more direct access to bison at different times.

\section{SITES}

There are a number of East Texas and Northwest Louisiana sites occupied by ancestral Caddo groups that have bison bone remains and tools, as well as a few ornaments of bison bone, although in a few instances the identifications are problematic. These sites are found in the Pineywoods, Post Oak Savannah, and Blackland Prairie habitats in the region (Figure 1). In this article, I discuss these sites by river basin, providing information on the number and kind of bison remains found on East Texas and Northwest Louisiana Caddo sites, as well as their likely age. None of the bison remains from these Caddo sites have been directly dated by radiocarbon methods. Without the direct dating of bison remains, conclusions regarding bison presence in the Caddo area of East Texas are based only on association with other archaeological remains, such as temporally diagnostic ceramic vessels with distinctive decorative motifs whose ages have been established within broad temporal parameters, and this kind of association is less preferable than direct dating of bison remains to establish their precise temporal contexts on sites. 


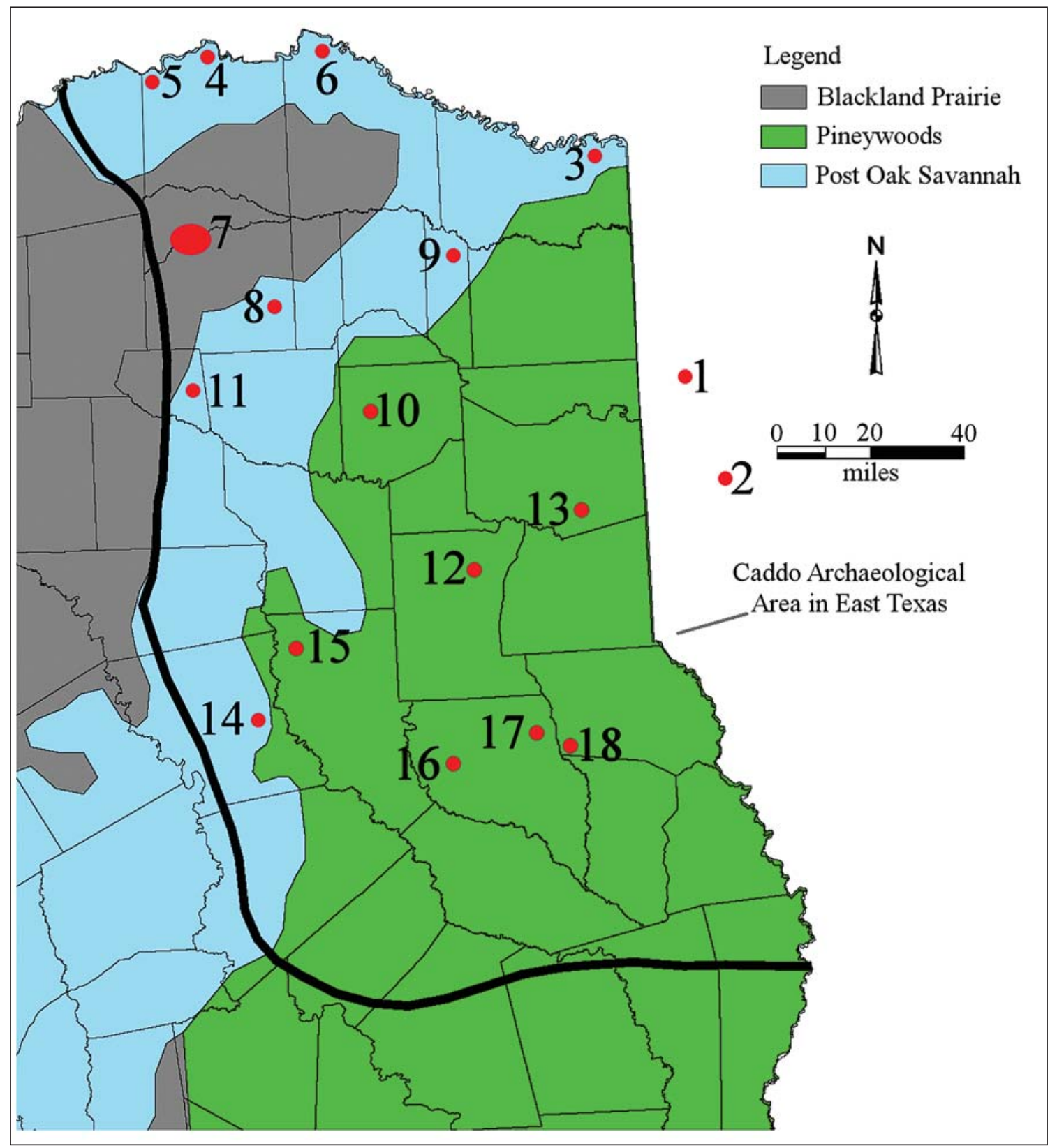

Figure 1. Locations of sites where bison remains and/or tools or ornaments have been recovered in East Texas Caddo sites: 1, Belcher; 2, McLelland; 3, Roseborough Lake; 4, Womack; 5, Sanders; 6, Sam Kaufman; 7, Cooper Lake sites (Spike, Hurricane Hill, and Peerless Bottoms); 8, Tuinier Farm, Watkins, and Anglin; 9, 41MX5; 10, Lake Gilmer sites; 11, Gilbert; 12, Oak Hill Village; 13, Pine Tree Mound; 14, Alcoa \#1; 15, Jim P. Allen; 16, Deshazo; 17, Tallow Grove; 18, Tyson.

\section{Red River Basin}

Caddo sites with bison bones are found in both the East Texas and Northwest Louisiana parts of the Red River basin. According to Schambach (2003:218, see also Neuman 1983), no bison remains have been found in any part of Arkansas, and the Red River basin in Arkansas "contains no good bison habitat." These sites in East Texas and Northwest Louisiana in the Red River basin range in age from as early as the Middle Caddo period (ca. A.D. 1200-1400) to as late as ca. A.D. 1750. 


\section{Roseborough Lake (41BW5)}

Bison-sized animal bone, including molar, radius, and rib pieces, have been recovered from early to mid-18th century Nasoni Caddo archaeological deposits at the Roseborough Lake site on the Red River (Yates 1986:Table III.1). Yates (1986:125) concluded that "small herds of bison would have wintered nearby, but may have been too far to efficiently exploit or too far to bring back a carcass that would leave osteological evidence."

\section{Womack (41LR1)}

One disturbed burial at the Womack site on the Red River had a bison scapula hoe in association. Womack Engraved vessels in this burial indicate that it was occupied between ca. A.D. 1700-1730 (see Harris et al. 1965; Perttula 2015a).

\section{Sanders (41LR2)}

A number of bison scapula hoes and hoe fragments were recovered by University of Texas archaeologists in midden deposits between the two mounds and in Mound No. 1 (the burial mound) at the Sanders site (Jackson et al. 2000:34). Krieger (1946:183) indicates that this includes 18 hoes and hoe blades.

The archaeological deposits at the site are not well-dated, but one radiocarbon date has been recently obtained on deer bone from midden deposits. A deer phalange has a conventional radiocarbon age of 374 \pm 24 years B.P. (A.D. 1552-1600). The 2 sigma calibrated age range of this date is A.D. 1448-1631, with a median calibrated age of A.D. 1503. At 2 sigma, the age range probabilities are A.D. 1448-1524 (63 percent) and A.D. 1572-1631 (32 percent). This $16^{\text {th }}$ to possible early $17^{\text {th }}$ century calibrated date from the Sanders site is not inconsistent with the nature of the archeological record known from the site (Krieger 1946; Perttula et al. 2015a).

Several Middle Caddo period (ca. A.D. 1100-1300, although the Sanders phase is not well dated) burials in Mound No. 1 also had bison scapula hoe funerary offerings, including Burials 7 (Individual A), 14, and 20 (Individual 3). Jackson et al. (2000:32) and Krieger (1946:184) noted that collectors had previously found two other such hoe from excavated burials at the Sanders site.

The National Museum of Natural History collections from the Sanders site has a notched bison bone rib and two bison scapula hoe fragments (Perttula et al. 2015a:Figure 45e). These were apparently collected from village archaeological deposits, which include ca. A.D. 1100-1300 and ca. A.D. 1680-1730 components.

\section{Roitsch (41RR16)}

Excavations in the McCurtain phase (ca. A.D. 1400-1680) archaeological deposits at the Roitsch site recovered two animal bones from very large mammals, cf. Bos/Bison (Yates 2008:Table 47). Radiocarbon dates from the site from this component date the occupation from the early 15 th century to the early 17 th century A.D., though the recovery of glass beads from several burials indicate that the occupation continued to at least ca. A.D. 1700-1730. Excavations in a cemetery area along the banks of Red River recovered a bison bone leg bone and two bison rib tools from a burial that dates to the late $17^{\text {th }}$ century-early $18^{\text {th }}$ century, based on the recovery of a Keno Trailed, var. Phillips bowl among the funerary offerings (Perttula et al. 2012).

\section{Belcher (16CD13)}

Although not in East Texas, the Middle to Late Caddo period Belcher site on the Red River in Northwest Louisiana had "cow or bison, one metacarpal and two phalanges" (Webb 1959:180) in the Mound B deposits. However, Webb (1959:180-181) also commented on "the absence of bison bones...Evidently the hunting of 
these animals was not part of this village's economy or customs, or bison were absent from this area during the period of occupation. This absence has been noted from other sites in this area."

\section{McLelland (16BO236)}

A single bison right ulna shaft fragment was found in Structure 1 excavations at the McLelland site along the Red River in Northwest Louisiana (Kelley 1997:104 and Table 22). This Caddo site was occupied from ca. A.D. $1650-1710$.

\section{Sulphur River Basin}

The Sulphur River basin Caddo sites with bison remains include three sites in the upper Sulphur River basin at Cooper Lake, another three sites along a tributary to White Oak Creek in the upper part of the basin, and one site in the middle part of the Sulphur River basin. The earliest evidence of bison use in East Texas - ca. A.D. 600-800 - is in one of the Cooper Lake sites, and another site at Cooper Lake has bison in an archaeological deposit that dates from ca. A.D. 1000-1200. The other five sites with bison remains date to the Late Caddo period, between ca. A.D. 1430-1680.

\section{Spike (41DT16)}

Yates (1993:325 and Table 51) reports the presence of three bison bones (three pieces of tooth enamel) in Analysis Unit 3 archaeological deposits at the Spike site at Cooper Reservoir in the upper Sulphur River basin. Henderson (1978:78) had previously noted a bison or cow phalanx from test excavations at the site. Fields et al. (1993:92) suggest that Analysis Unit 3 dates to ca. A.D. 600-800.

\section{Hurricane Hill (41HP106)}

The Hurricane Hill site is a multi-component prehistoric site on an upland landform overlooking the South Sulphur River at Cooper Lake (Perttula 1999). Four very large artiodactyla bones (possibly from bos/bison or elk) were recovered in the excavations (Yates 1999:Table 13-1), although Yates (1999:348) concluded that there was no bison bones identified, and overall grasslands animals were rare. Yates (1999) did not indicate the spatial or temporal contexts of these few bones, but about 90 percent of the recovered identified fauna from the site came from the North rise, and the predominant occupation there was during the Early Caddo period (ca. A.D. 1000-1200).

\section{Peerless Bottoms (41HP175)}

Only two bison or possible bison (i.e., cow/bison/elk) bones have been found at the Peerless Bottoms site (Yates 1993:330 and Table 53). The Caddo occupation at the site dates to the latter half of the 15th century A.D. (Fields et al. 1993:177; Fields et al. 1997).

\section{Tuinier Farm (41HP237)}

The Tuinier Farm site is one of three Late Caddo period Titus phase settlements in the Stouts Creek valley in the upper Sulphur River basin (Perttula 2009a) that have bison remains; the others are Watkins (41HP238) and Anglin (41HP240). They are situated in the modern-day Post Oak Savannah. The material culture remains found at the three sites indicates they date from ca. A.D. 1550-1680.

The Tuinier Farm site had one bison bone from midden deposits (Schniebs 2009:Table 21). The bone is an incisor with a drilled hole (Schniebs 2009:Figure 59b), and may have been worn as a pendant. 


\section{Watkins (41HP238)}

The one bison bone at the Late Caddo period Watkins site is also an drilled incisor (Schniebs 2009:73 and Figure 59d).

\section{Anglin (41HP240)}

Midden deposits at the Anglin site contain bison remains: 16 individual specimens and one minimum number of individuals (Schniebs 2009:Table 21); two of the pieces are burned (Schniebs 2009:Table 23). The remains include two drilled incisors (Schniebs 2009:Figure 59e-f) and a number of post-cranial elements.

\section{$41 \mathrm{MX} 5$}

A single very-large sized mammal bone, possibly from one bison, was found in the ca. 15th century archaeological deposits at 41MX5 in the mid-Sulphur River basin (Brewington et al. 1995:Table 34). Acceptable calibrated radiocarbon dates from the site have ranges between A.D. 1331-1487 and A.D. 14171465 (Brewington et al. 1995:Table 45).

\section{Big Cypress Creek Basin}

All three of the Caddo sites with bison remains in the Big Cypress Creek basin are from sites investigated at Lake Gilmer in the Little Cypress Creek drainage (see Figure 1). The Lasco (41UR106) and Kelsey Creek (41UR118) sites have primarily Late Caddo period components (post-A.D. 1450), while both Middle Caddo period (ca. A.D. 1200-1450) and Late Caddo components are present in different blocks at the Rookery Ridge site (41UR133).

\section{Lasco (41UR106)}

There are two bison bones from the ca. A.D. 1450-1550 Titus phase component at the Lasco site (41UR106), probably from one juvenile individual. One of the bones, a calcaneum fragment, has a cut mark on it (Parsons 2011:Appendix B).

\section{Kelsey Creek Dam (41UR118)}

Although Parsons (2011:Appendix B) indicated that bison remains were recovered at the Kelsey Creek dam site, he provides no information on the number of such remains or their intra-site context. Most of the bone from the site came from excavations associated with Features 1 and 2, which were small pits with well-preserved faunal remains.

Calibrated radiocarbon dates from the site are A.D. 1460-1700 (2 sigma, 70.4 percent), A.D. 1420-1645 (2 sigma), and A.D. 1400-1520 (88.0 percent). The 95 percent probability age ranges overlap between A.D. 1460-1530 and A.D. 1590-1630 (Parsons 2011). The A.D. 1460-1530 age range for any bison remains from the site conforms most reasonably to the recovered Titus phase artifacts found there.

\section{Rookery Ridge (41UR133)}

The bison bone (the exact number of bison in the faunal assemblage is not provided) from the Rookery Ridge site is from Block S (Parsons 2011:Table B.2). This occupation is apparently of Middle Caddo period age. The one reasonable calibrated radiocarbon dates from this area of the site is A.D. 1280-1400. 


\section{Sabine River Basin}

Five different sites in the upper and mid-Sabine River basin have bison remains (see Figure 1). These are from ancestral Caddo deposits that date as early as ca. A.D. 1150-1300, and the occupations date as well to the Late Caddo and Historic Caddo periods, from ca. A.D. 1626-1691 and ca. A.D. 1750-1775.

\section{Gilbert (41RA13)}

The Gilbert site is a historic Caddo settlement principally occupied from ca. A.D. 1750-1775 in the Lake Fork Creek valley in the upper Sabine River basin (Jelks 1967:244). Bison bone remains (n=9 NISP and four MNI, Lorrain 1967a:Table 11) were recovered from six different midden features on the western part of the site (Jelks 1967:Figure 1); almost 90 percent of the animal bones from the site were those of white-tailed deer. One of the bones is an incisor with a hole drilled through the root portion of the tooth (Lorrain 1967b:212) - similar to previously mentioned bison tooth ornaments from several post-A.D. 1550 Caddo sites in the upper Sulphur River basin, and another is a bison scapula hoe from the Feature 4 midden deposit (Lorrain 1967b:Figure 75h).

\section{Oak Hill Village (41RK214)}

The Oak Hill Village site is a large ca. A.D. 1150-1400 Caddo village on a tributary of the Sabine River (Rogers and Perttula 2004). A mandibular fragment from a single bison is present in the Area A faunal remains from the site (Nash et al. 2004:323 and Table 84). This area was occupied primarily between A.D. 1150-1300 (Rogers and Perttula 2004:Figure 110).

\section{Pine Tree (41HS15)}

A single deer/bison-sized mammal bone was recovered in Feature 2.068 in Area $2 \mathrm{~N}$ excavations at the Pine Tree Mound site in the mid-Sabine River basin (Fields and Gadus 2012:847). This is one of the many village areas in this large mound and village site investigated by Fields and Gadus (2012:Figure 2.3). Feature 2.068 is a large pit with more than 800 faunal remains (Fields and Gadus 2012:203-207 and Table 4.6). One radiocarbon date from this feature has 2 sigma calibrated age ranges of A.D. 1626-1691 (40 percent probability) and A.D. 1728-1811 (41 percent probability) (Fields and Gadus 2012:Table 4.13); the A.D. 1626-1691 age range is most reasonable given the associated artifacts found in the fill of the large pit.

\section{Earl Jones Farm (41WD3)}

The Earl Jones Farm site is a Late Caddo period Titus phase (ca. A.D. 1430-1550) habitation site along a tributary stream in the Lake Fork Creek basin, in the upper Sabine River basin, of the East Texas Post Oak Savannah (Perttula 2015b). Among the animal bones recovered in the midden mound at the site is one possible bison toe bone (1986 Texas Archeological Research Laboratory inventory sheets).

\section{L. Winterbauer (41WD6)}

The L. L. Winterbauer site (41WD6) is an ancestral Caddo habitation site in the Lake Fork Creek basin in the Post Oak Savannah of East Texas (Perttula 2015c). It is situated along a small tributary stream that flows west into Lake Fork Creek, itself a tributary to the Sabine River. The recovered artifacts from the investigations of the Winterbauer site indicate that the site was occupied during the Late Caddo period Titus phase, dated generally between ca. A.D. 1430-1550. Among the recovered animal bones from the site are two possible bison bones: a long bone fragment and a mandible of a juvenile. 


\section{Neches River Basin}

Two Caddo sites in the upper Neches River basin have bison remains, either from midden or burial contexts. Bison occurs in archaeological deposits at the sites that date to either the early 15 th century or from ca. A.D. $1680-1730$.

\section{Alcoa \#1 (41AN87)}

The Alcoa \#1 site is on Mound Prairie Creek in the upper Neches River basin. It is a single component 15th century A.D. Frankston phase Caddo site. Calibrated radiocarbon dates obtained from charred nutshells from $30-40 \mathrm{~cm}$ bs and $50-60 \mathrm{~cm}$ bs in midden deposits are: A.D. 1380-1514 (2 sigma, 75 percent probability) and AD 1294-1437 (2 sigma, 95.4 percent probability), respectively. Calibrated intercepts of the two radiocarbon age ranges are A.D. 1426 and A.D. 1407 (level 6), suggesting an occupation that began in the early $15^{\text {th }}$ century A.D. (Perttula 2009b). Bison remains were recovered at the base of the midden deposits (Amick et al. 1991).

\section{Jim P. Allen (41CE12)}

A modified bison bone was recovered as a funerary offering in burial AH-7 at the Jim P. Allen site in the upper Neches River basin. The Caddo cemetery at the site dates to ca. A.D. 1680-1730, during the early part of the Allen phase.

\section{Angelina River Basin}

The three Caddo sites with bison remains in the Angelina River basin are on tributaries, namely Bayou Loco and Naconiche Creek, of either the Angelina River or Attoyac Bayou. Bison occurs in archaeological deposits that date from ca. A.D. 1300-1480 and ca. A.D. 1700-1730.

\section{Deshazo (41NA27)}

Bison/Bos remains were found on the surface in Area $\mathrm{F}(\mathrm{n}=1)$ of the Deshazo as well as in Unit 2 excavations in the habitation deposits at the Historic Caddo Deshazo site on Bayou Loco in the Angelina River basin (Henderson 1982:Table 19). The Deshazo site was occupied between ca. A.D. 1700-1730 (Story 1982). None of these Bison/Bos remains were "positively identifiable" as bison (Henderson 1982:150). Henderson (1982:150) suggests that the absence of bison at the site was the result of the fact that:

the bones of the butchered animals were not brought back to the site. Ethnohistoric accounts refer to the butchering of bison at the kill site, where the meat was then deboned, dried, and cut into strips for transportation back to the village.

\section{Tallow Grove (41NA231)}

A large faunal assemblage was recovered in excavations at the Tallow Grove site $(n=11,634)$ (Schniebs 2008:Table 10-1). Among these is one very large mammal bone (1 MNI), probably from a bison. This site was primarily occupied between ca. A.D. 1300-1480 (Perttula 2008).

\section{Tyson (41SY92)}

The Tyson site is on an alluvial terrace overlooking the confluence of Attoyac Bayou and Naconiche Creek in the Angelina River basin. This settlement likely dates from ca. A.D. 1390-1440. An analysis of a sample of the recovered faunal remains identified one cf. Bison bison bone (middle phalange) from Feature 
3 (Tom Middlebrook, November 1, 2014 personal communication; Shaffer n.d.). The one bone had been burned and spirally fractured. Feature 3 is one of two juvenile burials excavated in the area of a Caddo structure at the site (Middlebrook 2014).

\section{Trinity River Basin}

Although just outside of the East Texas ancestral Caddo culture area, the Winston site (41HE245) on the Trinity River in the Post Oak Savanna has two bison bone elements (Richner and Bagot 1978:161). These bison bones were in a lower buried shell lens that merged with an upper shell lens that contained arrow points, dart points and nine ceramic sherds. It is likely that these bison bones date after ca. A.D. 700, when arrow points began to be manufactured in the region and the use of ceramic vessels began to intensify.

Another site on the Trinity River in the Post Oak Savannah, the Wright Creek site (41HO341) has a toe bone that is bison-sized. This bone came from a pre-A.D. 700 Woodland period context (Perttula et al. 2015).

\section{Temporal Contexts}

The 26 ancestral Caddo sites discussed herein have archaeological deposits that contain bison bones, tools, or ornaments that range in age from as early as ca. A.D. 600-800 to as late as ca. A.D. 1775 (Table 1). These age estimates for the occurrence of bison bones on Caddo sites in East Texas and Northwest Louisiana are based on archaeological association (i.e., the association between the bison bones and temporally diagnostic artifacts) as well as radiocarbon dates from archaeological deposits, not on the direct dating of bison remains (c. Lohse et al. 2014a, 2014b).

Table 1. Temporal association of bison remains in East Texas and Northwest Louisiana ancestral Caddo sites.

\begin{tabular}{lll}
\hline Temporal intervals & East Texas & Northwest Louisiana
\end{tabular}

\section{Woodland period}

A.D. $600-800$

Early to Middle Caddo period

A.D. $1000-1200$

A.D. $1150-1300$

A.D. $1200-1400$

Middle Caddo to early Late

Caddo period

A.D. $1300-1480$

A.D. $1390-1440$

Late Caddo period

ca. A.D. $1430-1680$

ca. A.D. $1430-1500$

ca. A.D. $1450-1550$

ca. A.D. $1500-1680$

ca. A.D. $1550-1680$

ca. A.D. $1626-1691$

\section{1 site}

1 site

1 site

2 sites

1 site

1 site

1 site

3 sites

4 sites

$-$

3 sites

1 site

Late Caddo to Historic Caddo period A.D. $1650-1710$

1 site 
Table 1. Temporal association of bison remains in East Texas and Northwest Louisiana ancestral Caddo sites, cont.

\begin{tabular}{llc}
\hline Temporal intervals & East Texas & Northwest Louisiana \\
\hline Historic Caddo period & & - \\
A.D. $1680-1730$ & 1 site & - \\
A.D. $1700-1750$ & 3 sites & - \\
A.D. $1750-1775$ & 1 site & \\
\hline
\end{tabular}

There is a ca. 200 year hiatus between the one Late Woodland site with bison in the upper Sulphur River basin and the occurrence of bison again in Caddo sites in East Texas (see Table 1). Only four of the 24 East Texas Caddo sites with bison (16.7 percent) were occupied between ca. A.D. 1000-1400, and two other sites (in the Angelina River basin) were occupied between ca. A.D. 1300-1480 and ca. A.D. 1390-1440.

Bison remains are much more common in Caddo sites in East Texas after ca. A.D. 1430 (see Table 1). Seven sites (29 percent), were occupied between ca. A.D. 1430-1550, based both on radiocarbon dating of archaeological deposits as well as the associated temporally diagnostic material culture remains, and another four sites (16.7 percent) were occupied between ca. A.D. 1550-1690. One other Late Caddo site in East Texas with bison has only broader temporal estimates, unfortunately: being occupied between ca. A.D. 1430-1680. This period is also the time when Caddo pottery is more common in areas of Central and East Central Texas where Caddo groups were hunting bison (Creel et al. 2013:74).

In the historic Caddo period, four of the East Texas sites with bison bones (16.7 percent) were occupied between ca. A.D. 1680-1750. The last of the known Caddo sites in East Texas with bison bones was occupied between ca. A.D. 1750-1775 (see Table 1).

The two Northwest Louisiana sites with bison remains date between ca. A.D. 1500-1710 (see Table 1). These were relatively wet years, except for a major droughty period between A.D. 1564-1573 (Cook et al. n.d.).

\section{Environmental Contexts}

Droughts are not uncommon in the region in modern times, and dendrochronological analysis suggests there were numerous wet and dry spells between ca. A.D. 1000-1700, just as there were between 5000-1000 years ago. Some of the worst droughts may have occurred around A.D. 1555, 1570, 1595, and 1670, and the period between A.D. 1549-1577, or A.D. 1564-1573, has been suggested to have been years when the worse droughts occurred in the past 450 years (Cook et al. n.d.; Stahle et al. 1985), at least in parts of the mid-continent. Another severe droughty period appears to have taken place between about A.D. 1440-1475.

Fields and Gadus' (2012:Figure 1.6) review of a broad-ranging data base on droughts in this part of Northeast Texas - and their severity based on the Palmer Drought Severity Index - indicates that the worst droughts took place in the A.D. 1440s-1450s and the A.D. 1560s; the A.D. 1440s-1450s drought had the worst drought severity index. Other significant periods of drought (listed from severe to less severe) occurred in the A.D. 1340 s-1350s, A.D. 1640 s, A.D. 1360 s-1380s, ca. A.D. 1510, the A.D. 1760s-1770, ca. A.D. 1530, and the A.D. 1720s. Caddo sites occupied during some of these droughty periods, particularly those after A.D. 1400, have evidence that the site occupants were procuring bison products.

More detailed dendrochronological analyses from bald cypress tree-ring chronologies on spring rainfall between A.D. 1002-1815 from Big Cypress State Park in northwestern Louisiana (Stahle and Cleaveland 1995 ) indicate the wettest years were between A.D. 1053-1057, 1168-1176, 1178-1180, 1265-1268, 1323$1328,1553-1555,1584-1586,1718-1719,1797-1800$, and 1810-1812 (Figure 2 and Table 2). The wetter rainfall conditions would also likely have led to an increase in the extent of swamp and wetland habitats 
in the major stream basins, and a concomitant expansion in the carrying capacity of woodland plants and animals in the area. In historic times - after ca. 1650 - the wettest interval occurred between 1797-1815. Bison were likely being exploited by Caddo groups during some of these wetter periods as well, especially wetter periods after the mid-A.D. 1200s.

Table 2. Climatic Conditions between A.D. 1014-1699 based on the 1000 year dendrochronological record from Big Cypress State Park in northwestern Louisiana.

\begin{tabular}{|c|c|c|c|}
\hline $\begin{array}{l}\text { Drier Periods } \\
\text { (A.D.) }\end{array}$ & Mean tree-ring width & $\begin{array}{l}\text { Wetter periods } \\
\text { (A.D.) }\end{array}$ & $\begin{array}{l}\text { Mean tree- } \\
\text { Ring width }\end{array}$ \\
\hline 1014-1016 & 462 & & \\
\hline \multirow[t]{3}{*}{ 1044-1045 } & 568 & & \\
\hline & & $1053-1056$ & 1823 \\
\hline & & $1165-1180$ & 2005 \\
\hline $1215-1217$ & 520 & & \\
\hline \multirow[t]{2}{*}{$1233-1234$} & 512 & & \\
\hline & & $1265-1280$ & 1745 \\
\hline 1293-1294 & 376 & & \\
\hline \multirow[t]{3}{*}{$1312-1313$} & 507 & & \\
\hline & & $1323-1328$ & 1803 \\
\hline & & $1357-1359$ & 1577 \\
\hline \multirow[t]{4}{*}{ 3178-1379 } & 463 & & \\
\hline & & $1391-1398$ & 1554 \\
\hline & & $1428-1429$ & 1660 \\
\hline & & $1438-1440$ & 1610 \\
\hline $1446-1447$ & 285 & & \\
\hline $1455-1460$ & 380 & & \\
\hline \multirow[t]{2}{*}{$1472-1473$} & 556 & & \\
\hline & & $1483-1487$ & 1529 \\
\hline \multirow[t]{7}{*}{$1529-1533$} & 466 & & \\
\hline & & $1540-1541$ & 1571 \\
\hline & & $1553-1555$ & 1790 \\
\hline & & $1577-1578$ & 1975 \\
\hline & & $1580-1581$ & 1589 \\
\hline & & $1584-1586$ & 1675 \\
\hline & & $1610-1615$ & 1887 \\
\hline $1653-1655$ & 426 & & \\
\hline 1697-1699 & 476 & & \\
\hline
\end{tabular}

Note: the driest years have mean standard tree-ring indices of less than 560, while the wetter years have standard tree-ring indices greater than 1400 .

On the other hand, the driest years in prehistoric and early historic times in East Texas-between A.D. 1014-1016, 1215-1217, 1444-1447, 1455-1460, 1529-1533, 1653-1655, 1697-1699, 1841-1846, and 1855-1860 - may well have led to stressed food supplies or different options in food procurement, such as the acquisition of bison products from neighboring hunter-gatherer groups living in the Brazos and Colorado River basins (e.g., Lohse 2014a, 2014b) to the west of East Texas. The drier periods did not influence the character of Caddo settlement systems, which remained dispersed throughout the prehistoric and early historic periods, but it did influence their distribution across the landscape, as Caddo agricultural populations began to concentrate in the Pineywoods and along certain major streams (i.e., the Red, the lower 


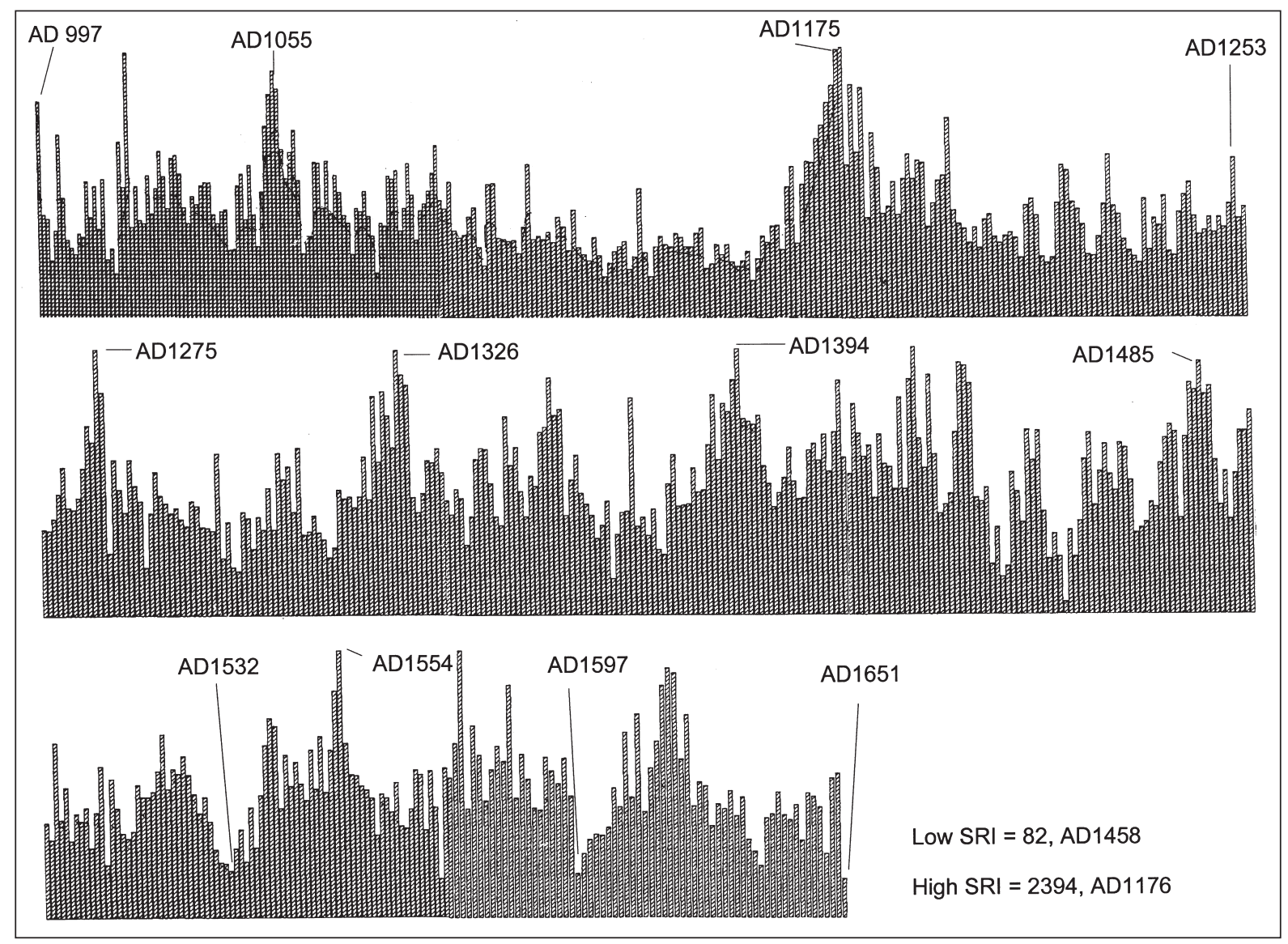

Figure 2. Tree-ring sequence, Big Cypress State Park, Louisiana, A.D. 997-1651.

Sulphur, the middle Sabine, and certain parts of the Neches-Angelina river basins). Caddo sites in all these areas were obtaining small amounts of bison products during these years.

The very dry years between A.D. 1444 and 1460 correlate well with the grass spike/drier episode noted by Bousman (1998) from the Weakly Bog pollen record. These more significant droughts probably affected the relative quantity of animal and plant foods in floodplain and upland forested habitats. By A.D. 1444, droughty conditions ensued for much of the next 16 years (until A.D. 1460). During this time it was generally drier and colder, with much drier and colder climatic minima at ca. 500 (Sporer Minima) and 300 years ago (Maunder Minima) as identified by changes in reconstructed solar radiation (Bradley et al. 2003:Figure 6-13) (Figure 3a). There were mesic (warmer and wetter) intervals particularly after 410 years ago (see Table 2), but the driest conditions during this period (and indeed over the last 1000 years) occurred between A.D. 1446-1460. Very droughty years between 1841-1846 correlate closely with the final abandonment of East Texas by the Caddo.

For the period of wet and dry spells from ca. A.D. 1000-1650, the wetter years ( $>1400$ standard ring width indices [sri]) were more than two times as frequent as the driest and droughty $(<560 \mathrm{sri})$ years (see Figure 2). After ca. A.D. 1430, the wetter years occurred less often, some 55 percent less between A.D. 1600-1700 than was the case in the ca. A.D. 1200-1400 period. In historic times, the wettest but also most equitable interval was between A.D. 1792-1826, with the wetter years eight times more common than the very dry and droughty years. Conversely, in the period between A.D. 1827-1861, the very dry and droughty years outnumbered the very wet years by a ratio of 9:1. These very different paleoenvironmental conditions over long periods of time likely played an important role in East Texas in human adaptations and the episodic occurrence of bison in and in areas near East Texas. 


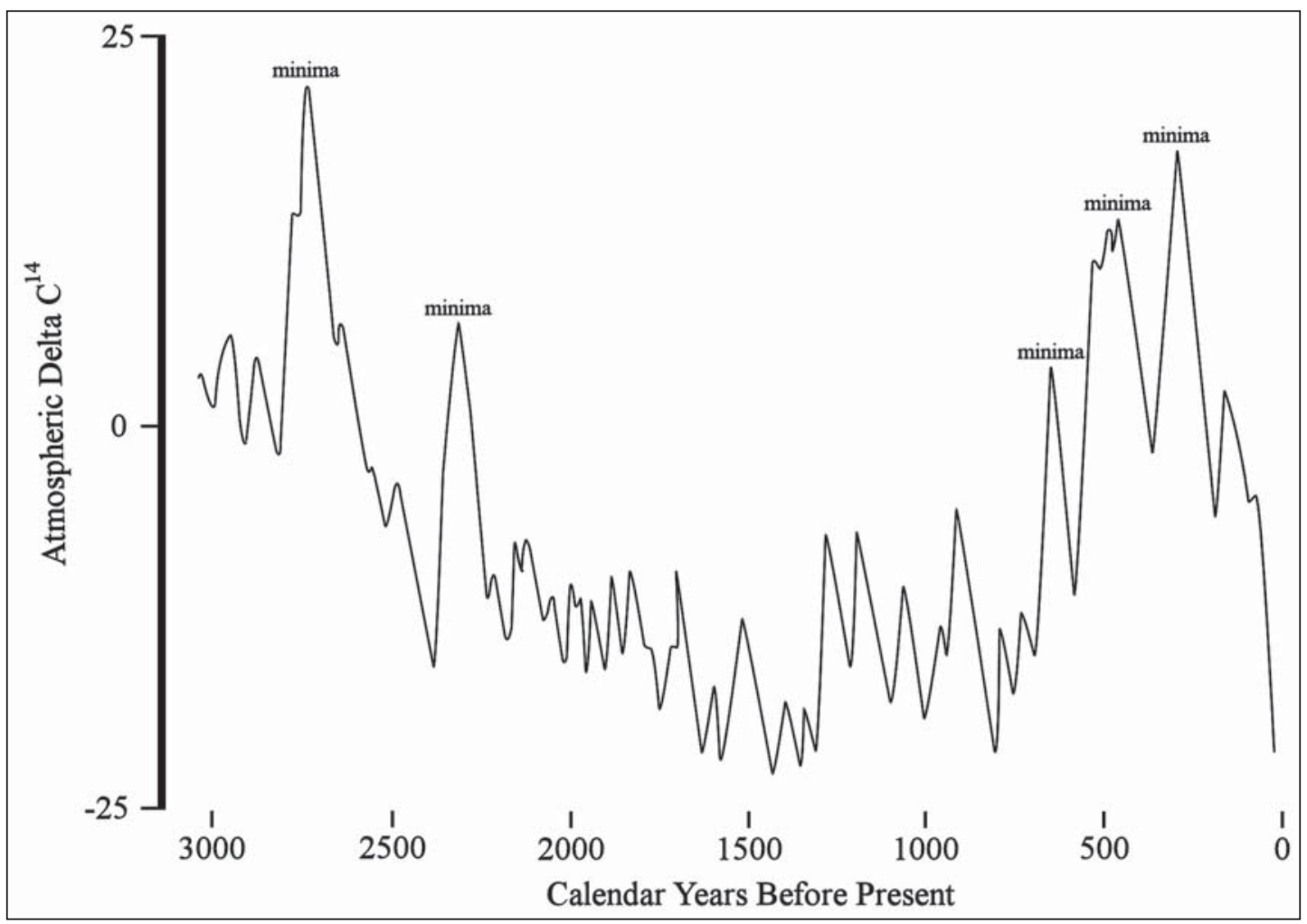

Figure 3. Changes in atmospheric delta $\mathrm{C} 14$ and climatic minima: a, 3000 years B.P. to the present.

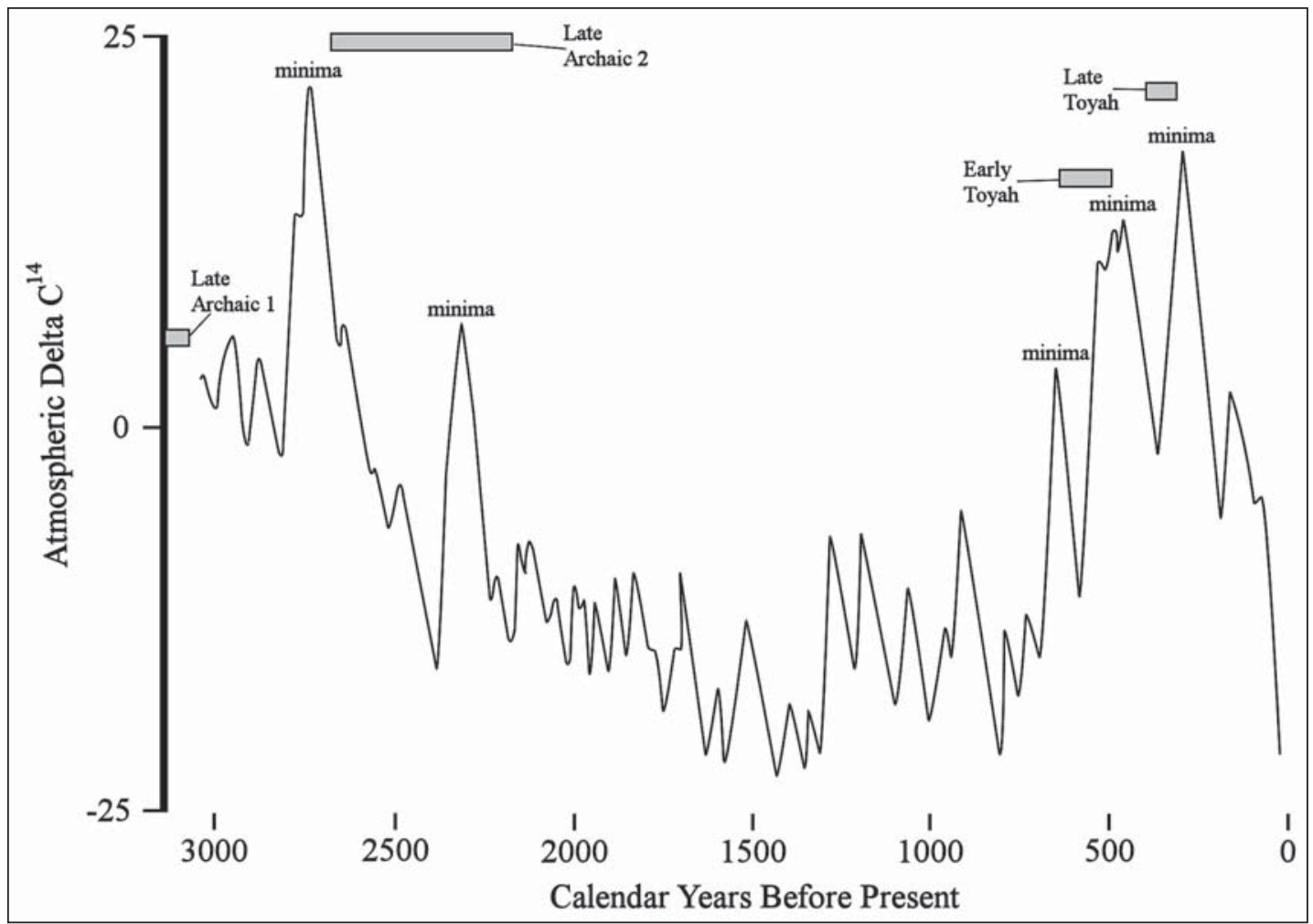

Figure 3. Changes in atmospheric delta $\mathrm{C} 14$ and climatic minima: b, climatic minima and the occurrence of bison in Central Texas sites. 


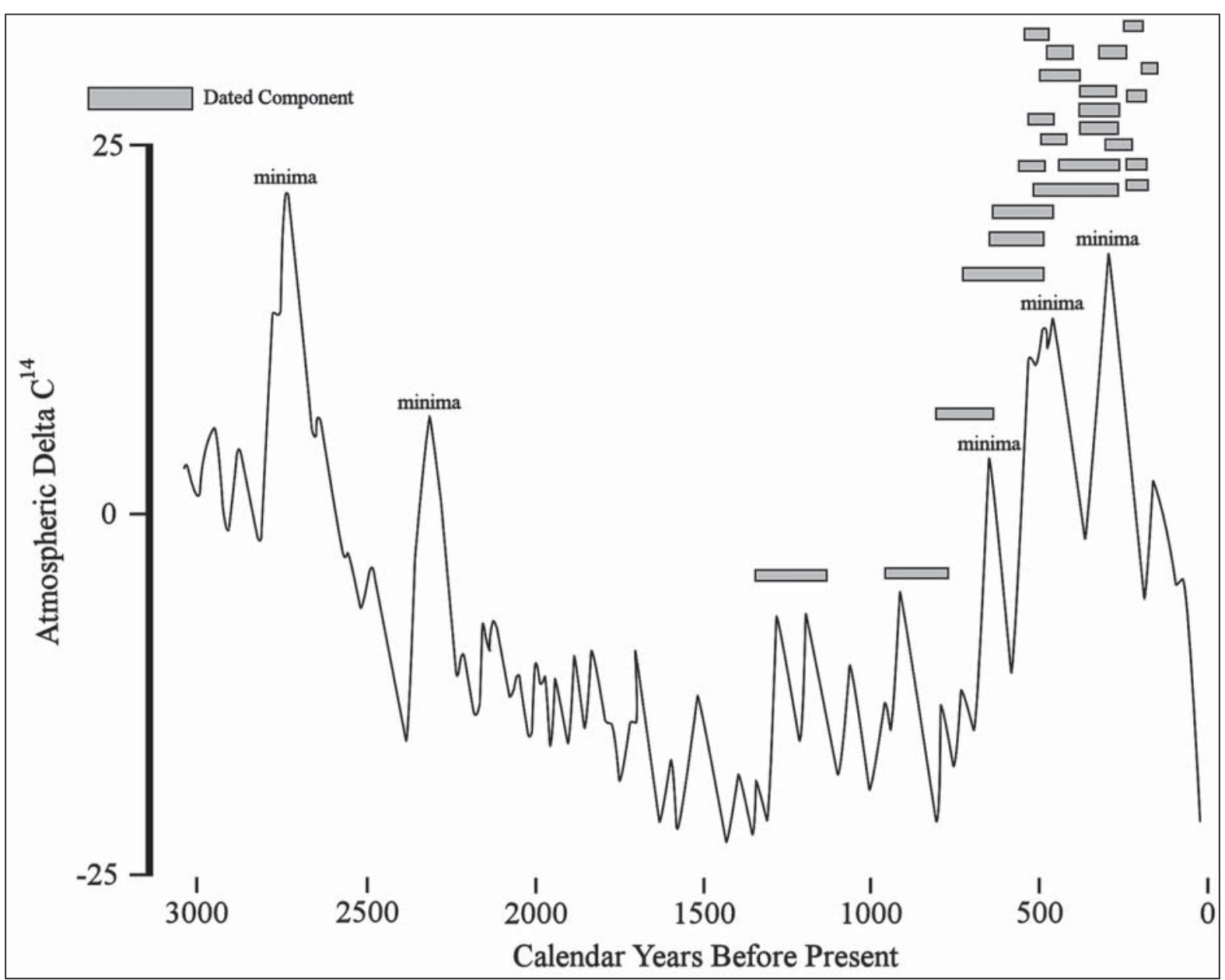

Figure 3. Changes in atmospheric delta $\mathrm{C} 14$ and climatic minima: c, climatic minima and the occurrence of bison in Caddo sites.

The mean temperature reconstructions indicate that there has been a general decline in temperature from about A.D. 1000 (if not earlier) to about A.D. 1900, with a rapid warming after that time. Crowley's (2000) studies suggest that prior to A.D. 1850, decadal-scale changes in temperature variation are due to low frequency changes in solar irradiance and pulses in volcanism that served as climatic forcing mechanisms. The $11^{\text {th }}$ and $12^{\text {th }}$ centuries were warm, and the $13^{\text {th }}$ century was a time of temperature fluctuations, as was the $14^{\text {th }}$ century and much of the $15^{\text {th }}$ century. Some of the coldest reconstructed temperatures occurred around the mid $-14^{\text {th }}$ century (perhaps during the Wolf Minima), as well as in the mid $-15^{\text {th }}$ century, and much of the $17^{\text {th }}$ century was cool (Figure 4). Otherwise, much of the period between ca. A.D. 1300 and 1580 was relatively warm. After A.D. 1700, temperatures warmed again, until a period of abrupt cooling in the early part of the $19^{\text {th }}$ century. Other reconstructions of past temperature variability over the last 1000 years suggests that the $17^{\text {th }}$ century was even colder than previously thought, and much of the $12^{\text {th }}, 13^{\text {th }}$, and $14^{\text {th }}$ centuries were cool (Esper et al. 2002; Mann 2002).

Because bison occurs more commonly on Caddo sites dating after ca. A.D. 1430, what were climatic conditions like during that time? From trends in tree ring width and reconstructed mean temperature variation, six alternating droughty and mesic periods have been defined between A.D. 1430 and 1680 in the East Texas region (Table 3). The droughty periods date from A.D. 1430 to 1476 (during the Sporer Minima), A.D. 1525 to 1538 , and from A.D. 1573 to 1602 , and the generally warmer and wetter periods date from A.D. 1477 through 1524, A.D. 1539 through 1572, and from A.D. 1603 through 1670+. After A.D. 1670, the period from A.D. 1671 to 1676 was relatively dry and cool. 


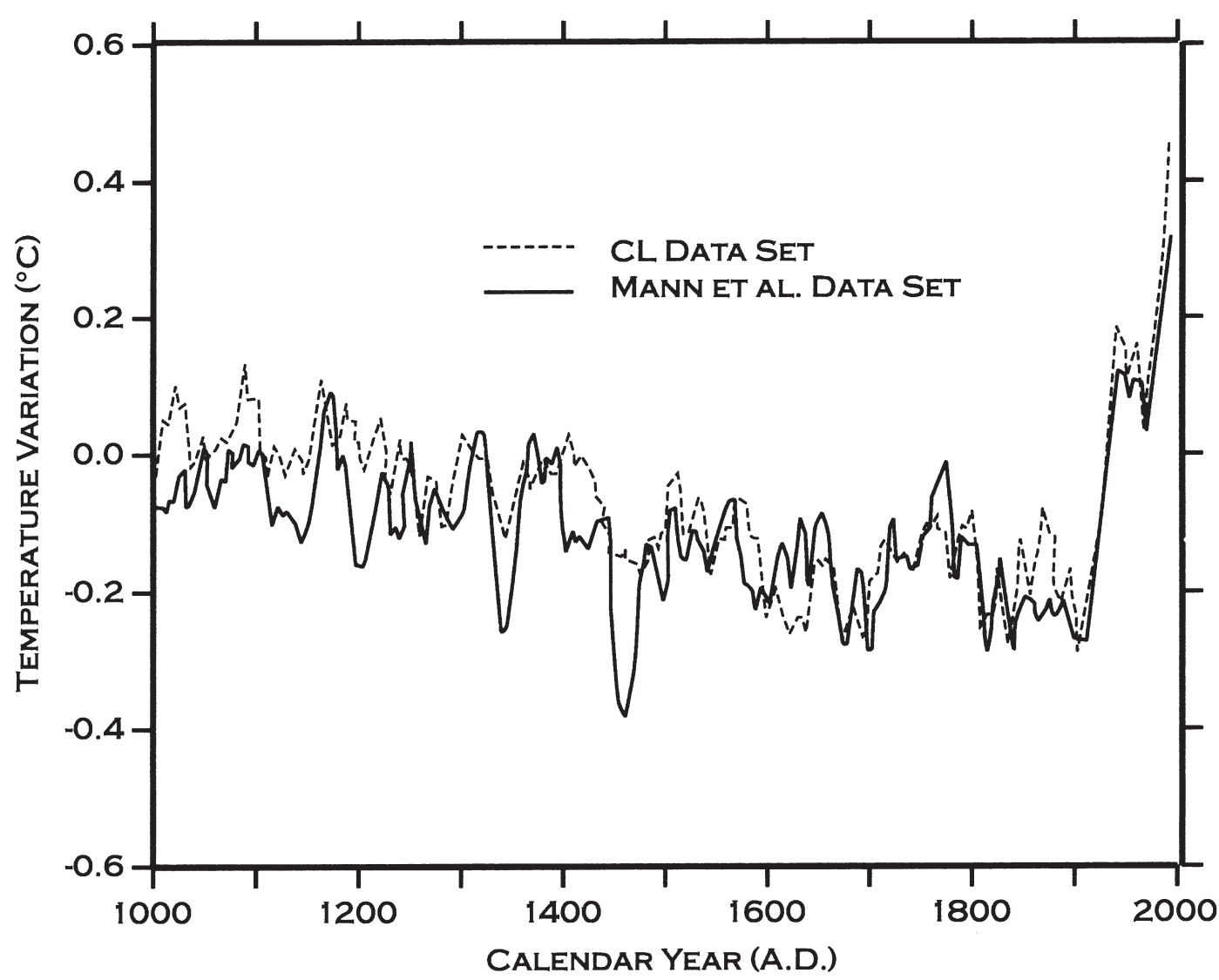

Figure 4. Reconstructed temperature variation, A.D. 1000-2000, after Mann et al. (1998) and Crowley (2000).

Table 3. Reconstructed Climatic Episodes, A.D. 1430-1680.

\begin{tabular}{llll}
\hline Climatic Episode & Droughty periods & $\begin{array}{l}\text { Mean Tree-Ring } \\
\text { Width in droughty } \\
\text { Periods }\end{array}$ & $\begin{array}{l}\text { Mesic } \\
\text { periods }\end{array}$ \\
\hline A.D. $1430-1476$ & $\mathrm{X}$ & $\begin{array}{l}370.5(1444-1447) \\
380.5(1455-1460)\end{array}$ & \\
& & $556.0(1472-1473)$ & \\
& & & $\mathrm{X}$ \\
A.D. $1477-1524$ & $\mathrm{X}$ & $466.0(1525-1538)$ & \\
A.D. $1525-1538$ & & & $\mathrm{X}$ \\
A.D. $1539-1572$ & $\mathrm{X}$ & $304.0(1573-1574)$ & \\
A.D. $1573-1602$ & & $487.5(1597-1598)$ & \\
& & $425.7(1651-1655)$ & $\mathrm{X}$ \\
A.D. $1603-1660+$ & & & \\
\hline
\end{tabular}

Note: the lower the mean tree-ring width, the drier the climate. A mean standard ring width of 1000 represents an equitable climate and average growing and moisture conditions. 
Based on mean tree-ring widths in the three principal droughty climatic episodes, the most sustained and persistent period of drought was in the A.D. 1430 to 1476 climatic episode (see Table 3). The three peaks of drought conditions in A.D. 1444 to 1447, 1455 to 1460, and in 1472 to 1473 had mean tree ring widths of only $370.5-556.0$, between $40-60$ percent lower than in times of an equitable climate and average growing and moisture conditions. The A.D. 1455 through 1460 drought was also a notably colder era.

The other two droughty climatic episodes were also very dry (with mean tree-ring widths ranging between 304 and 487.5), some 50 to 70 percent lower than in average climatic conditions. These drier and colder drought periods, and the four-year drought (A.D. 1651 to 1655) during the last mesic period, did not generally last as long as the cold and dry pulses during the A.D. 1430 to 1476 period. While the A.D. 1525 through 1538 droughty period was quite dry, it was nowhere as severe a drought as the drought in the mid-16 $6^{\text {th }}$ century that Stahle et al. (2000:121) consider the "most severe prolonged drought over much of North America for at least the last 500 years." This period of persistent drought occurred between about A.D. 1560 to 1590 in parts of Texas and between A.D. 1540 and 1580 in northern Mexico, with the worst years in the mid-1570s in Texas - apparently indicated by the two very dry years in 1573 and 1574 - with very low summer precipitation. Reconstruction of the spatial extent of this mid- $16^{\text {th }}$ mega-drought by Cook et al. $(1999$, n.d.) suggests its effects were more severe from southern Texas to the panhandle of Texas, and then north and west into the southwestern U.S., and were less intensely felt in the Caddo area.

In Central Texas after ca. 3000 years B.P., bison remains are found on sites that date to times of climatic minima (see Figure 3b). To summarize the occurrence of bison on Caddo sites relative to broad-scale environmental changes, it also appears to be the case that bison remains are found on Caddo sites in East Texas and Northwest Louisiana during times of climatic minima, as most of them were occupied at the time of the Wolf (ca. A.D. 1250 midpoint), Sporer (ca. A.D. 1450 midpoint), or Maunder (ca. A.D 1700 midpoints) minima (see Figure 3c). Comparing tree ring and temperature variation data to the occurrence of bison remains on ancestral Caddo sites, these sites were occupied during both dry and mesic intervals, with fluctuating temperatures; the coolest periods were in the mid-15th and late 17th-early 18th centuries A.D. (see Figure 4), times when bison remains were most commonly found on East Texas and Northwest Louisiana Caddo sites.

\section{Historic Accounts}

Finally, historic records concerning the Caddo exploitation of bison are illuminating. For instance, various Spanish accounts indicate that from the 1690 s to the mid $-18^{\text {th }}$ centuries, if not earlier as well as later, East Texas Caddo groups had been hunting bison herds between the Trinity and Colorado rivers in prairie habitats (Foster 1995:40, 112). Fray Casanas, who lived among the Hasinai Caddo groups in East Texas in 1690, noted that the Caddo men traveled west (to the Brazos and Colorado River basins) to hunt bison (Casanas 1968:44; Creel et al. 2013:75). According to Foster (1998:193, fn4) "there was no report of bison east of the Trinity by any seventeenth- or eighteenth-century Spanish expedition diarist."

The cooler and wetter climates at that time period created vegetation conditions "sufficient to sustain sizeable herds of the large animals" (Foster 1995:236). In 1768, Solis noted that bison herds were not found east of the Trinity River, but were near the Navasota River, more than $40 \mathrm{~km}$ west of the Trinity (Kress 1931:59-60). Earlier, Nasoni Caddo hunters from Red River communities had taken 46 bison during a twoweek hunt in 1719 north of the Red River in the Kiamichi River valley in southeastern Oklahoma (Smith 1959:382); this is during the Maunder climatic minima. In later historic times among the Kadohadacho, namely in the early $19^{\text {th }}$ century (before 1830), bison were noted to occur in large herds in the Bodcau Prairie in the Red River basin in Northwestern Louisiana (Webb 1959:10); this is in the Dalton Minima (ca. A.D. 1820 midpoint). 


\section{SUMMARY AND CONCLUSIONS}

Bison remains have been recovered and identified on 26 ancestral Caddo sites in the East Texas and Northwest Louisiana regions. The distribution of bison remains both temporally and spatially across the region provides evidence that bison herds were episodically present in grassland habitats that could be reached by pre-horse Caddo peoples. They also provide direct evidence that certain Caddo communities procured bison at different specific times, most notably after ca. A.D. 1430/1450, but also at different times from as early as ca. A.D. $600-800$ to ca. A.D. 1775; the Caddo peoples had horses at this late date.

There is one Late Woodland site (occupied ca. A.D. 600-800) with bison in the upper Sulphur River basin. Only four of the 24 East Texas Caddo sites with bison were occupied between ca. A.D. 1000-1400, and two other sites were occupied between ca. A.D. 1300-1480 and ca. A.D. 1390-1440.

Bison remains are common in Caddo sites in East Texas only after ca. A.D. 1430. Seven sites were occupied between ca. A.D. 1430-1550, and another four sites were occupied between ca. A.D. 1550-1690. This period of time is also when Caddo pottery is more commonly found in areas of Central and East Central Texas where Caddo groups were hunting bison (Creel et al. 2013:74). In the historic Caddo period, four of the East Texas sites with bison bones were occupied between ca. A.D. 1680-1750. The last of the known Caddo sites in East Texas with bison bones was occupied between ca. A.D. 1750-1775. The two Northwest Louisiana sites with bison remains date between ca. A.D. 1500-1710. These were relatively wet years.

Paleoenvironmental conditions in the general region during the ancestral Caddo occupation suggests that the presence of bison occurred during periods favorable to grassland forage. Isotopic reconstructions also suggest that bison herds that could have been hunted by Caddo peoples in Central Texas were present during colder periods, periods of rapid climate change, with variations in effective moisture. Bison remains are found on Caddo sites in East Texas and Northwest Louisiana during times of climatic minima, at ca. A.D. 1250 , ca. A.D. 1450, and ca. A.D 1700. Tree ring and temperature variation indicates these periods were either dry or mesic intervals, with fluctuating temperatures; the coolest periods were in the mid-15th and late 17th-early 18th centuries A.D., which were times when bison remains are most commonly found on East Texas and Northwest Louisiana Caddo sites.

\section{ACKNOWLEDGMENTS}

Thanks to Jon Lohse for his review and useful comments on this article.

\section{REFERENCES CITED}

Amick, C., E. Furman, T. K. Perttula, J. E. Bruseth, and B. C. Yates

1991 ALCOA \#1 (41AN87): A Frankston Phase Settlement along Mound Prairie Creek, Anderson County, Texas. Caddoan Archeology Newsletter 2(2):11-15.

Bousman, C. B.

1998 Paleoenvironmental Change in Central Texas: The Palynological Evidence. Plains Anthropologist 43(164):201-219.

Bradley. R. S., K. R. Briffa, J. Cole, M. K. Hughes, and T. J. Osborn

2003 The Climate of the Last Millennium. In Paleoclimate, Global Change, and the Future, edited by K. D. Alverson, R. S. Bradley, and T. F. Pedersen, pp. 105-141. Springer-Verlag, Berlin.

Brewington, R. L., J. E. Dockall, and H. J. Shafer

1995 Archaeology of 41NX5: A Late Prehistoric Caddoan Hamlet in Morris County, Texas. Reports of Investigations No. 1. Center for Environmental Archaeology, Texas A\&M University, College Station. 
Casanas, F.

1968 Relacion sobre los indios del este de Texas. In Primeras Exploraciones y Poblamiento de Tejas (16861694), Noticias Geograficos e Historicas del Noreste de Mexico, edited by L. Gomez Canedo, pp. 39-69. Instituto Technologico y de estudios superiors de Monterrey, Mexico.

Cook, E. R., D. M. Meko, D. W. Stahle, and M. K. Cleaveland

1999 Drought Reconstruction for the Continental United States. Journal of Climate 12:1145-1162.

Cook, E. R., R. Seager, M. A. Cane, and D. W. Stahle

n.d. North American Droughts: Reconstruction, Causes, and Consequences. http://www.ideo/columbia.edu/ res/div/ocp/pub/cook/Cook_Seager_Cane_Stahle.pdf. Accessed October 27, 2014.

Creel, D.

1991 Bison Hides in Late Prehistoric Exchange in the Southern Plains. American Antiquity 56(1):40-49.

Creel, D., J. R. Ferguson, and N. A. Kenmotsu

2013 A Compositional Analysis of Central Texas Hunter-Gatherer Ceramics and Its Implications for Mobility, Ethnic Group Territory, and Interaction. Bulletin of the Texas Archeological Society 84:29-83.

Crowley, T. J.

2000 Causes of Climate Change Over the Past 1000 Years. Science 289:270-277.

Doehner, K., D. Peter, and S. A. Skinner

1978 Evaluation of the Archaeology of the Proposed Cooper Lake. Research Report No. 114. Archaeology Research Program, Southern Methodist University, Dallas.

Esper, J., E. R. Cook, and F. H. Schweingruber

2002 Low-Frequency Signals in Long Tree-Ring Chronologies for Reconstructing Past Temperature Variability. Science 295:2250-2253.

Fields, R. C. and E. F. Gadus (editors)

2012 Archeology of the Nadaco Caddo: The View from the Pine Tree Mound Site (41HS15), Harrison County, Texas. 2 Vols. Reports of Investigations No. 164. Prewitt and Associates, Inc., Austin.

Fields, R. C., M. E. Blake, and K. W. Kibler

1997 Synthesis of the Prehistoric and Historic Archeology of Cooper Lake, Delta and Hopkins Counties, Texas. Reports of Investigations No. 104. Prewitt \& Associates, Inc., Austin.

Fields, R. C., E. F. Gadus, L. W. Klement, C. B. Bousman, and J. B. McLerran

1993 Excavations at the Tick, Spike, Johns Creek, and Peerless Bottoms Sites, Cooper Lake Project, Delta \& Hopkins Counties, Texas. Reports of Investigations No. 91. Prewitt \& Associates, Inc., Austin.

Foster, W. C.

1995 Spanish Expeditions into Texas, 1689-1768. University of Texas Press, Austin.

Foster, W. C. (editor)

1998 The La Salle Expedition to Texas: The Journal of Henri Joutel, 1684-1687. Texas State Historical Association, Austin.

Harris, R. K., I. M. Harris, J. C. Blaine, and J. Blaine

1965 A Preliminary Archeological and Documentary Study of the Womack Site, Lamar County, Texas. Bulletin of the Texas Archeological Society 36:287-365.

Henderson, J.

1978 Faunal Analyses. In Evaluation of the Archaeology of the Proposed Cooper Lake, by K. Doehner, D. Peter, and S. A. Skinner, pp. 77-86, 108-115, and 200-207. Research Report No. 114. Archaeology Research Program, Southern Methodist University, Dallas. 
1982 Faunal Analysis. In The Deshazo Site, Nacogdoches County, Texas, Volume 1, edited by D. A. Story, pp. 131-157. Texas Antiquities Permit Series No. 7. Texas Antiquities Committee, Austin.

Jackson, A. T., M. S. Goldstein, and A. D. Krieger

2000 The 1931 Excavations at the Sanders Site, Lamar County, Texas: Notes on the Fieldwork, Human Osteology, and Ceramics. Archival Series 2. Texas Archeological Research Laboratory, The University of Texas at Austin.

Jelks, E. B. (editor)

1967 The Gilbert Site: A Norteno Focus Site in Northeastern Texas. Bulletin of the Texas Archeological Society $37: 1-248$.

Kelley, D. B. (editor)

1997 Two Caddoan Farmsteads in the Red River Valley: The Archeology of the McLelland and Joe Clark Sites. Research Series No. 51. Arkansas Archeological Survey, Fayetteville.

Kress, M. K. (translator)

1931 Diary of a Visit of Inspection of the Texas Missions Made by Fray Gaspar Jose de Solis in the Year 1767-68. Southwestern Historical Quarterly 35:28-76.

Krieger, A. D.

1946 Culture Complexes and Chronology in Northern Texas, with Extensions of Puebloan Datings to the Mississippi Valley. Publication No. 4640. The University of Texas, Austin.

Lohse, J. C., B. J. Culleton, S. L. Black, and D. J. Kennett

2014a A Precise Chronology of Middle to Late Holocene Bison Exploitation in the Far Southern Great Plains. Journal of Texas Archeology and History 1:94-126.

Lohse, J. C., D. B. Madsen, D. J. Kennett, and B. J. Culleton

2014b Paleoecological Implications of a High-Precision Chronology for Episodic Mid-to-Late Holocene Bison Population Expansions in the Southern Plains, U.S.A. Quaternary Science Reviews 102(2014):14-26.

Lorrain, D.

1967a Animal Remains. In The Gilbert Site: A Norteno Focus Site in Northeastern Texas, edited by E. B. Jelks. Bulletin of the Texas Archeological Site 37:225-243.

1967b Bone and Shell Artifacts. In The Gilbert Site: A Norteno Focus Site in Northeastern Texas, edited by E. B. Jelks. Bulletin of the Texas Archeological Site 37:212-219.

Mann, M. E.

2002 The Value of Multiple Proxies. Science 297:1481-1482.

Mann, M. E., R. S. Bradley, and M. K. Hughes

1998 Northern Hemisphere Temperatures during the past Millennium: Inferences, Uncertainties, and Limitations. Geophysical Research Letters 26:759-762.

Middlebrook, T.

2014 Early European Descriptions of Hasinai Elites and Understanding Prehistoric Caddo Mortuary Practices in Shelby County, Texas. Bulletin of the Texas Archeological Society 85:83-110.

Nash, M. L. Shaw, and R. Rogers

2004 Faunal Analysis. In The Oak Hill Village Site (41RK214), Rusk County, Texas, by R. Rogers and T. K. Perttula, pp. 323-327. Document No. 030083. PBS\&J, Austin.

Neuman, R. W.

1983 The Buffalo in Southeastern United States Post-Pleistocene Prehistory. In Southeastern Natives and Their Pasts: A Collection of Papers Honoring Dr. Robert E. Bell, edited by D. G. Wyckoff and J. L. Hofman, pp. 261-280. Studies in Oklahoma's Past No. 11. Oklahoma Archeological Survey, Norman. 
Parsons, M.

2011 Mitigation Phase Archeological Investigations at Lake Gilmer, Upshur County, Texas. MS on file, Archeology Division, Texas Historical Commission, Austin.

Perttula, T. K.

2009a The Archaeology of the 16th and 17th Century Caddo in the Post Oak Savannah of Northeast Texas: The Tuinier Farm (41HP237), R. A. Watkins (41HP238), and Anglin (41HP240) Sites in the Stouts Creek Basin, Hopkins County, Texas. Journal of Northeast Texas Archaeology 30:1-132.

2009b Frankston Phase Ceramics from the Alcoa \# 1 (41AN87) Site, Mound Prairie Creek, Anderson County, Texas. Journal of Northeast Texas Archaeology 29:23-44.

2015a The Womack Site (41LR1), an Ancestral Caddo Settlement on the Red River in Lamar County, Texas. Journal of Northeast Texas Archaeology 52:1-38.

2015b A Titus Phase Midden Mound at the Earl Jones Farm (41WD3) in the Lake Fork Creek Basin, Wood County, Texas. Journal of Northeast Texas Archaeology 53:11-21.

2015c The L. L. Winterbauer Site (41WD6), Wood County, Texas. Journal of Northeast Texas Archaeology 53:23-35.

Perttula, T. K. (editor)

1999 The Hurricane Hill Site (41HP106): The Archaeology of a Late Archaic/Early Ceramic and Early-Middle Caddoan Settlement in Northeast Texas. 2 Vols. Special Publication No. 4. Friends of Northeast Texas Archaeology, Pittsburg and Austin.

2008 Lake Naconiche Archeology, Nacogdoches County, Texas: Results of the Data Recovery Excavations at Five Prehistoric Archeological Sites. 2 Vols. Report of Investigations No. 60. Archeological \& Environmental Consultants, LLC, Austin.

Perttula, T. K., B. Nelson, and S. W. Ahr

2015b Archeological Survey Investigations on the Eastham State Prison Farm and Ferguson Prison Unit, Houston and Madison Counties, Texas. Report of Investigations No. 142. Archeological \& Environmental Consultants, LLC, Austin.

Perttula, T. K., B. Nelson, M. Walters, and R. Z. Selden Jr.

2015a The Sanders Site (41LR2): A Middle to Historic Caddo Settlement and Mound Center on the Red River in Lamar County, Texas. Journal of Northeast Texas Archaeology 50:1-87.

Perttula, T. K., M. Walters, and B. Nelson

2012 Early 1960s Excavations at the Sam Kaufman Site (41RR16), Red River County, Texas. Journal of Northeast Texas Archaeology 36:1-31.

Richner, J. J. and J. T. Bagot (assemblers)

1978 A Reconnaissance Survey of the Trinity River Basin 1976-1977. Research Report No. 113. Archaeology Research Program, Southern Methodist University, Dallas.

Rogers, R. and T. K. Perttula

2004 The Oak Hill Village Site (41RK214), Rusk County, Texas. Document No. 030083. PBS\&J, Austin.

Schambach, F. F.

2003 Osage Orange Bows, Indian Horses, and the Blackland Prairie of Northeastern Texas. In Blackland Prairies of the Gulf Coastal Plain: Nature, Culture, and Sustainability, edited by E. Peacock and T. Schauwecker, pp. 212-236. University of Alabama Press, Tuscaloosa.

Schniebs, L.

2008 Faunal Analyses. In Lake Naconiche Archeology, Nacogdoches County, Texas: Results of the Data Recovery Excavations at Five Prehistoric Archeological Sites, edited by T. K. Perttula, pp. 581-610. 2 Vols. Report of Investigations No. 60. Archeological \& Environmental Consultants, LLC, Austin. 
2009 Faunal Analysis of Three Late Caddo Sites in Hopkins County, Texas: Tuinier Farm, Anglin Midden, and the R. A. Watkins Site. Journal of Northeast Texas Archaeology 30:66-79.

Shaffer, B. S.

n.d. Analysis of the Vertebrate Remains from the Tyson Site, 41SY92. MS on file with the author.

Smith, R. A.

1959 Account of the journey of Benard de la Harpe: Discovery made by him of several nations situated in the West. Southwestern Historical Quarterly 62(1-4).

Stahle, D. W. and M. K. Cleaveland

1995 Texas Paleoclimatic Data from Daily to Millenial Time Scales. In The Changing Climate of Texas: Predictability and Implications for the Future, edited by J. Norwine, J. R. Giardino, G. R. North, and J. B. Valdes, pp. 49-69. GeoBooks, College of Geosciences and Maritime Studies, Texas A \& M University, College Station.

Stahle, D. W., M. K. Cleaveland, and J. G. Hehr

1985 A 450-Year Drought Reconstruction for Arkansas. Nature 316:530-532.

Stahle, D. W., E. R. Cook, M. K. Cleaveland, M. D. Therrell, D. M. Meko, H. D. Grissino-Mayer, E. Watson, and B. H. Luckman

2000 Tree-ring Data Document 16th Century Megadrought Over North America. Eos 81(12):121, 125. Transactions of the American Geophysical Union.

Story, D. A.

1982 The Deshazo Site, Nacogdoches County, Texas, Vol. 1: The Site, Its Setting, Investigations, Cultural Features, Artifacts of Non-Native Manufacture, and Subsistence Remains. Texas Antiquities Permit Series No. 7. Texas Antiquities Committee, Austin.

Webb, C. H.

1959 The Belcher Mound, a Stratified Caddoan Site in Caddo Parish, Louisiana. Memoirs No. 16. Society for American Archaeology, Salt Lake City.

Yates, B. C.

1986 Vertebrate Faunal Remains. In French-Indian Interaction at an 18th Century Frontier Post: The Roseborough Lake Site, Bowie County, Texas, by K. Gilmore, pp. 107-129. Contributions in Archaeology No. 3. Institute of Applied Sciences, North Texas State University, Denton.

1993 Zooarcheology of Four Woodland/Caddoan Sites at Cooper Lake. In Excavations at the Tick, Spike, Johns Creek, and Peerless Bottoms Sites, Cooper Lake Project, Delta \& Hopkins Counties, Texas, by R. C. Fields, E. F. Gadus, L. W. Klement, C. B. Bousman, and J. B. McLerran, pp. 307-333. Reports of Investigations No. 91. Prewitt \& Associates, Inc., Austin.

1999 Vertebrate Fauna from Hurricane Hill. In The Hurricane Hill Site (41HP106): The Archaeology of a Late Archaic/Early Ceramic and Early-Middle Caddoan Settlement in Northeast Texas, edited by T. K. Perttula, pp. 345-353. 2 Vols. Special Publication No. 4. Friends of Northeast Texas Archaeology, Pittsburg and Austin.

2008 Observations on the Faunal Remains from the 1991 Field School on the Red River in Red River County, Texas. In Collected Papers from Past Texas Archeological Society Summer Field Schools, edited by T. K. Perttula, pp. 458-478. Special Publication No. 5. Texas Archeological Society, San Antonio. 